\title{
ECONOMIC AND LEGAL ASSESSMENT OF THE VIOLATION OF PROPERTY RIGHTS DURING THE OCCUPATION OF AZERBAIJANI TERRITORIES
}

\author{
Nargiz Hajiyeva*1, Irshad Karimli² \\ ${ }^{1}$ Ph.D. candidate, independent researcher, International relations manager, Political Science, and \\ Sociology lecturer, Azerbaijan State University of Economics (UNEC), Baku, Azerbaijan ORCID ID: \\ https://orcid.org/0000-0002-9448-5613,nargiz_hajiyeva@unec.edu.az
}

${ }^{2}$ Professor, Head of Department of International Economics, Azerbaijan State University of Economics (UNEC), Baku, Azerbaijan, irshad.karimli@unec.edu.az

\begin{abstract}
The article mainly investigates the illicit exploitation of natural resources, goods, and products by Armenia during the occupation of Azerbaijani territories. The current legal and economic assessment of the property rights belong to those Azerbaijani lands are thoroughly conducted upon their liberation from occupation. The purpose of the study is to analyze the legal and economic scope of illegal activities after the occupation carried out by Armenia in the ancient lands of Azerbaijan. The selected topic is considered very high relevance not only in analytical respect but also in practical terms and has never deeply been researched before. Thus the economic and legal analysis of the illegalities committed during the occupation and measures taken after the liberation of Azerbaijani territories is comparatively estimated. In international politics, based on geographical indicators, property rights regulation in those territories has become a crucial problem in the process of illegal use of goods, items, and other resources amid the occupation. The country's rules and regulations, as well as provisions on property rights, its main contradictions, and emerging problems regarding the enforcement of property rights, are scrutinized in the article.
\end{abstract}

\section{Keywords}

Azerbaijan, exploitation, intellectual property, illegal activities, the liberation of Azerbaijani territories, property rights.

\section{JEL classification}

F5, K33, O34

DOI: https://doi.org/10.14311/bit.2021.01.05

Editorial information: journal Business \& IT, ISSN 2570-7434, CreativeCommons license (c) () published by CTU in Prague, 2021, http://bit.fsv.cvut.cz/ 


\section{Introduction}

Azerbaijan and Armenia do not have diplomatic or economic-trade relations due to the NagornoKarabakh conflict for 30 years. At the same time, there have been disagreements between the two countries regarding the protection of intellectual property rights and the customs system stemming from the illegal occupation of Azerbaijani territories; Nagorno-Karabakh, and its adjacent territories. The main reason for this is all of Azerbaijan's natural resources and products during the occupation have been falsified, then illegally stored and exported to international markets by Armenia. This, in turn, means that Azerbaijan's intellectual property rights had been infringed during the occupation. The United Nations Security Council (UNSC) adopted a number of resolutions in 1993, including 822 (1993), 853 (1993), 874 (1993), and 884 (1993), condemning the use of force against Azerbaijan and the occupation of its territories, reaffirming Azerbaijan's sovereignty and territorial integrity, acknowledging the Nagorno-Karabakh region as the main part of Azerbaijan, and the inviolability of its borders. [1,2,3,4] During the occupation, Armenia assertively encouraged and supported the production and export of illegal goods from occupied territories. Armenian authorities provided logistical support to Armenian and foreign businesses operating in those territories for them to promote their products on international markets, expand trade, develop ties with foreign business owners, and inspect investment opportunities. Prior to the liberation of these lands, the Armenian side in Azerbaijan's occupied territories shared a common customs zone with Armenia. As a result, at the time, the Armenian Customs Code governed imports to and exports from these territories. Unfortunately, Azerbaijan's customs system and spot checks, as well as the occupied territories, were demolished and had no legal status during the occupation period. Armenia violated the legally binding international obligations and principles derived from intellectual property law in those regions.

\section{Illicit exploitation of natural resources}

Armenian companies, as well as foreign companies mainly controlled by the diaspora: Lebanon's Artsax Roots Investment, the United States' Tufenkian Foundation, Armenia's General Benevolent Union / AGBU / Cherchian Family Foundation, have provided constant financial change. (including financial and monetary reform) both for personal gain and to carry out demographic and cultural changes in these areas during the occupation. [5] During the nearly 30 years of occupation of Azerbaijani lands, many international companies have been operating illegally here. Since 1999, the Armenian government has encouraged several foreign companies to invest in Karabakh. These influential companies violated the norms of international law and operated in the internationally occupied territories of Azerbaijan in the fields of mining, construction, woodworking, telecommunications, and others. More and more companies from Iran, the United States, Russia, Switzerland, Great Britain, France, Germany, the Netherlands, and other countries have illegally exploited Azerbaijan's wealth by investing in the occupied territories. The illegal activities of international companies in the occupied territories of Azerbaijan were also reflected in the reports of the Israeli Kohelet think tank in 2017 and 2018, entitled "Who else profits: international and European companies in the occupied territories." [6]

During the occupation, many international companies (160 international companies illegally operated in Karabakh) from French, (Orange, Crédit Agricole, Cartor, etc) the UK, (Grand Thronton" company, Vodafone), Germany (Aurubis, Deutz-Fahr), Russia, (Tashir Group, GeoProMining, Vibrotechnique), Netherland, (VimpelCom), the USA (ATA-Bank MS, GS Motors, Caterpillar, John Deere), Denmark (FLSmidth), Iran (Iran Mellat Bank), Switzerland (Franck Muller Group, Golden Fish), etc. established businesses in Azerbaijan by violating the principles of international law. Along with the abovementioned countries, companies from Lebanon, Canada, Portugal, Argentina, and other countries also set up businesses in Azerbaijan during the occupation. [7, 8,] Although Azerbaijan has repeatedly called on international organizations and the United Nations to fight illegal trade in Nagorno-Karabakh, these appeals have never been heeded. 
Extraction of precious minerals and metals in the occupied territories was considered one of the main activities. For example, the underground copper-gold mine in Gizilbulag (a subsidiary of the Armenian company Vallex Group CJSC, registered in Liechtenstein) was completely depleted. The same applies to the open copper-molybdenum mine in Demirli. In 2014, Gold Star CJSC started gold mining near the village of Veynalli (Zangilan district). It is reported that GPM Gold, a subsidiary of GeoProMiningLtd, which operates in Russia, had produced ore at the gold mine in the village of Soyudlu, Kalbajar region, since 2007. The famous Swiss brand watches were made of gold illegally exploited and exported from gold mines in the Vejnali village of Zangilan and Kalbajar, the occupied well-off territories of Azerbaijan. [9]

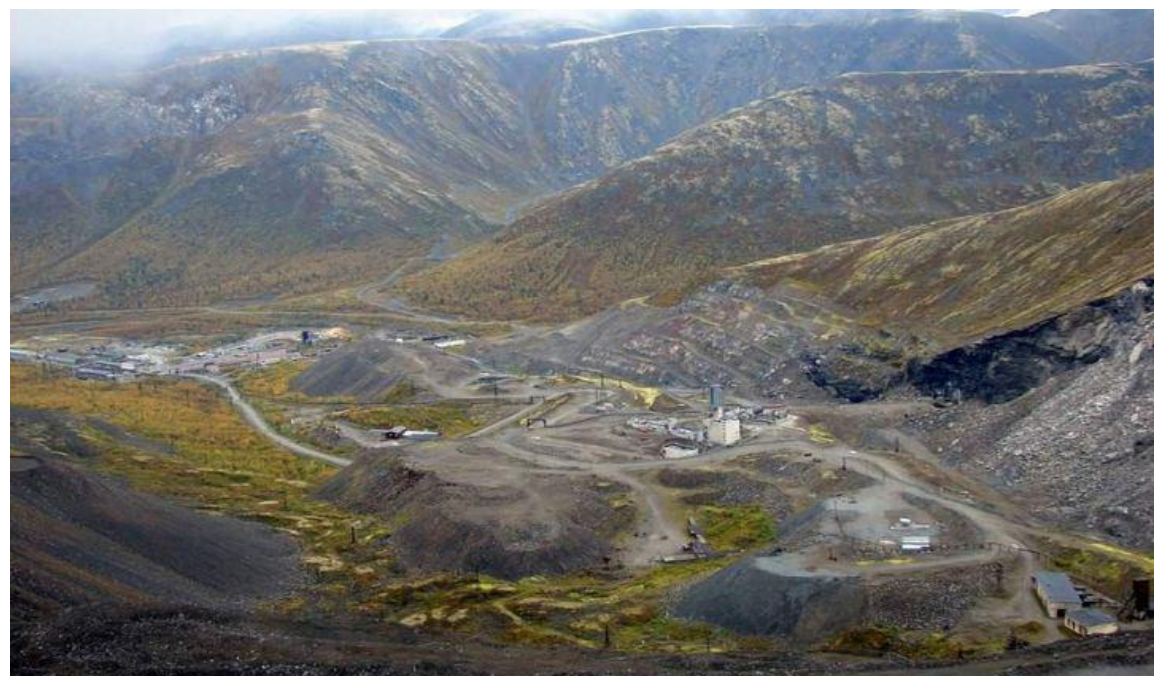

Figure 1. Gold mines were illegally exploited by Armenia in the Kalbajar region.

\section{Source: Azernews}

The Vardenis-Agdara highway was built for the illegal transportation of natural resources from the occupied region of the Azerbaijani-Armenian international border. [10] The Armenian government, through its energy ministry, transported ore concentrate directly from Gizilbulag to Armenia, where it processed gold-bearing copper and exported it to international markets, especially in Europe.

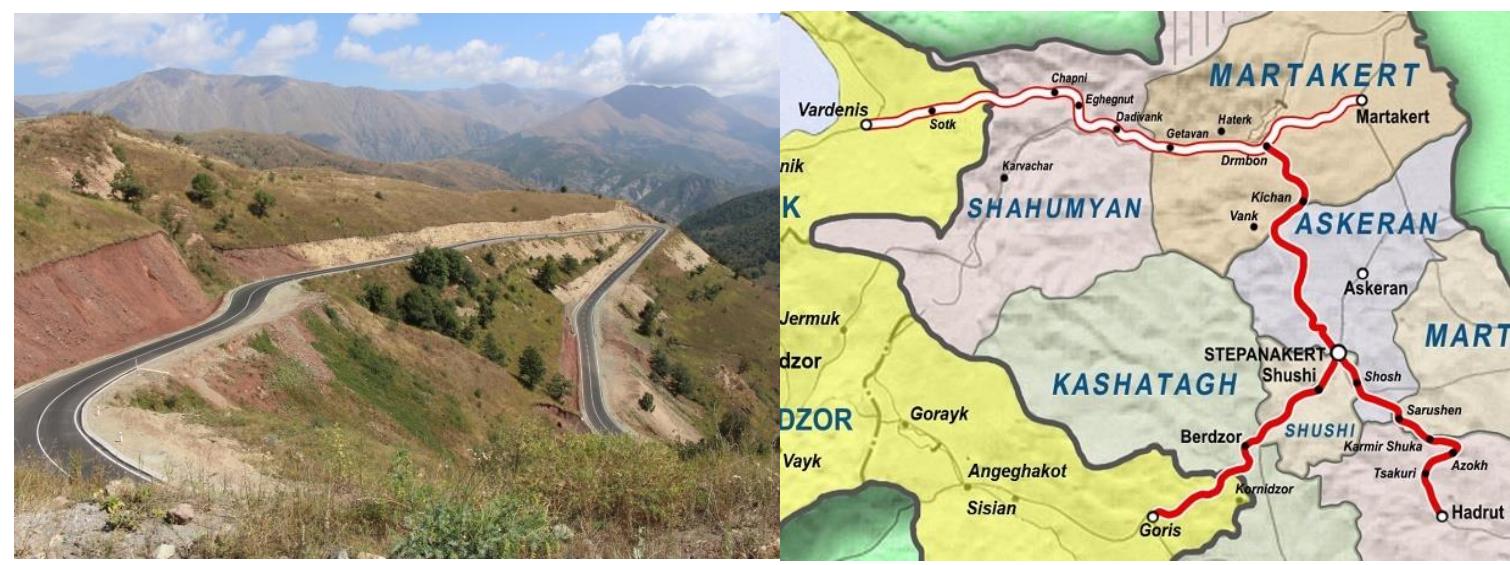

Figure 2. The Vardenis-Agdara highway, which was used for illegal activities/transportation during the occupation.

Source: Armenia Fund

In addition, coal was extracted from a mine near the occupied village of Chardagli in the Tartar region to supply a power plant in Yerevan. Therefore, in this epilogue, the secret displacement of the 
population and illegal economic activities in the occupied territories created a socio-political status quo, demographic displacement, and armed conflicts as a well-known "bloody diamond". [11] It can be argued that during the occupation, minerals, agriculture, water resources, and other natural resources were directly intended for Armenian and international "shadow" businesses. Here, based on demographic changes, human rights and humanitarian norms were violated through the implementation of fundamental contradictions, including IDPs.

\section{Illegal export issue and mislabelling}

Even before the liberation, the Armenian national currency known as "drama" was illegally used in Nagorno-Karabakh and its adjacent districts of Azerbaijan. During that time, the occupied territories are considered the main part of Armenia's economic territory, according to the Central Bank of Armenia (CBA), and all banking institutions operating in Karabakh had been licensed and controlled by the CBA. The banking system remained the focal point of the Armenian financial market at the time, with 528 branches in Armenia and Nagorno-Karabakh, 237 of which were in Yerevan. During the occupation, the Armenian government encourages commercial banks to open branches in occupied areas. At the same time, 8 Armenian banks are operating in the occupied territories, including Artsaxbank, Convers Bank, Ardshininvestbank, Armbusinessbank, Armeconombank, Araratbank, Unibank, and Ameriabank. [12] Armenia actively participates in the illegal exportation of Azerbaijani goods to neighboring countries. Armenia actively promoted businesses and their products operating in Azerbaijan's occupied territories. [13] During the occupation, there are regular reports of the destruction of houses, graves, cultural monuments in these areas of Azerbaijan, the transportation of equipment, construction materials, especially iron products, and other goods to other countries. Relevant information includes the fact that various precious metals, including gold-bearing soil, machine tools used in factories and plants, electric trains, wagons, and rails were cut and transported to other countries. There is information about the demonstration of our national treasures looted from the occupied territories - ancient historical works, carpets, minerals in European countries under the name of Armenian national treasure. Armenians exhibited photographs of mineral deposits and up to 3,600 rock carvings in Kalbajar in 2000 in Finland as their territory. [14]

In addition, the sale of ancient Azerbaijani musical instruments by Armenians in Europe, the CIS, and North America has increased, and Karabakh carpets have been put up for sale at various exhibitions and auctions under the name of Armenian or Persian carpets. In recent years, a large number of historical, cultural, and religious monuments in the occupied territories of Azerbaijan have been sold to foreign countries. Unique exhibits in museums in the occupied territories have either been destroyed or new museums have been created based on these exhibits, allegedly belonging to Armenians. In this sense, it should be noted that the Armenians attach special importance to the issue of appropriation of the monuments of ancient Caucasian Albania. Ancient Albanian inscriptions, wall patterns, and crosses on them were destroyed and replaced with Armenian attributes. Several mosques are used as warehouses. This campaign is purposeful and aimed at justifying the fact that these regions do not belong to Azerbaijan from the historical and cultural point of view and the settlement of Armenians in those areas. [14]

Even, at the "Made in Armenia Expo2015" exhibition, held in Yerevan on April 26-28, 2015, a separate stand was set up for the products of the so-called "Artsakh" (Original name is Karabakh). The wine factories of "Stepanakert Brandy Factory CJSC" were being run in the occupied Khojavand district, Gyrmyzy Bazar village, and the town of Khankandi, producing fruit vodkas, mulberry, and Stepanakert Brand Plant CJSC, which worked closely with the Yerevan Factory, exported liquor products to Russia, particularly Moscow, as well as Australia and Belgium. Stepanakert Brandy Factory" and "Artsakh Fruit CJSC" frequently mislabel products produced or packed in Azerbaijan's occupied territories to conceal the illicit nature of the origin of products/items to deceive foreign governments, international retailers, and consumers. $[15,16]$ 


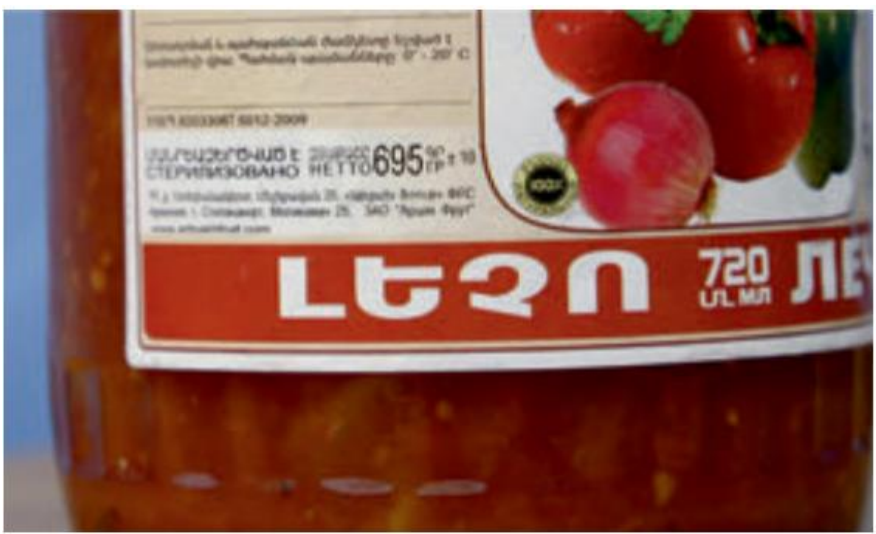

Figure 3. An illegal brand of the "Artsakh Fruit CJSC" product written "Stepanakert, Armenia in the Armenian language.

Source: www.vestnikkavkaza.net.

It is alleged that "Stepanakert Brandy Factory CJSC" registered its products, namely "Artsakh Mulberry (Silver and Gold Aged)", "Artsakh Apricot", "Artsakh Cornelian", "Berdashen", "Madatoff" vodkas, "Shushi (original name is Şuşa) Red", "Shushi Dry Pomegranate", "Gishi Rose" wine brand names, are traded to other countries under the label of "Product of Armenia" Simultaneously, Ohanyan brands and Avetissian wines were being exhibited in Los Angeles and Chicago with the "Armenian product".

$[17,18]$

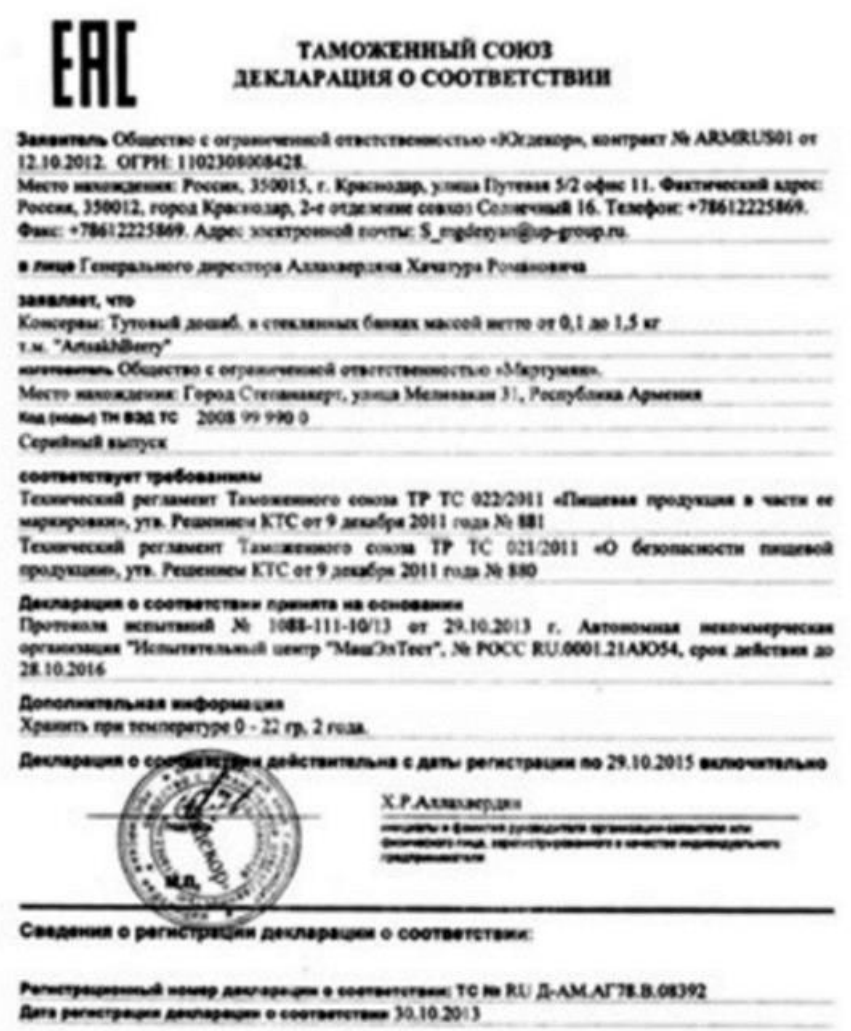

Figure 4. "ArtsakhBerry" products declaration of Customs by the Customs Union in Russia, Kazakhstan, Belarus, Armenia, Kyrgystan for the written that the products originate in "The town of Stepanakert, Melivakan Street 31, Armenia Republic.

Source: www.doshab.ru 
The illegal activities of Armenians have been repeatedly prevented by Azerbaijani officials and citizens living abroad. According to the Ministry of Economy, an investigation was launched into the illegal activities of Grand Thronton Armenia, a subsidiary of the London-based Grand Thronton International Company, in the occupied territories of Azerbaijan, the publication of business promotion publications and its ties with the Hayastan Foundation of Armenia. [19] In 2018, the Ministry of Economy immediately responded to the request of the Stepanakert Cognac Factory operating in the occupied city of Khankendi, Azerbaijan, to participate in the Prodexpo 2018 International Food Exhibition in Moscow, Russia, and to include the company's name in the exhibition catalog. Thus, it was stated that the participation of an enterprise operating illegally in the occupied territories of Azerbaijan in the International Food Exhibition "Prodexpo 2018" contradicts the norms of international law and is completely unacceptable. As a result of joint activities of the Ministry of Economy and the Embassy of the Republic of Azerbaijan in the Russian Federation, Expocentre OJSC prevented the participation of Stepanakert Cognac Factory in the Exhibition. The majority of "The Cognac Factory of Stepanakert» (which is also called Karabakh's Gold) production was exported to the Russian Federation, specifically Moscow. The factory worked closely with the Yerevan Cognac Factory. [20] During the occupation, the products and goods illegally produced in Azerbaijani territories were restricted to Armenian territory. As a result of a lack of enforcement measures and centralized policy and economic powers before the liberation of those lands, Azerbaijan was unable to take appropriate measures in the regulation of intellectual property in Nagorno-Karabakh and its adjacent areas.

\section{Conclusion}

In current years, Azerbaijan has made considerable progress in the regulation and justification of intellectual property rights, but it should be noted that there are still some challenges and paucities in intellectual property and property rights protection. During the occupation, Armenia actively encouraged and supported the production and export of illegal goods from occupied territories. It also used Azerbaijan's occupied territories as a transport base to deliver minerals and other resources both within the country and abroad. At the time, the Azerbaijani customs system had been destroyed in the occupied territories, and the country was having difficulty protecting its property rights in NagornoKarabakh and the seven districts that bordered it. Armenia's illegal economic and other activities on ancient Azerbaijani lands are completely contrary to international intellectual property conventions and continue to violate them. Azerbaijan calls on international partners to face criminal charges if its sovereignty and territorial integrity are violated, including prosecution of those who attempted to assist in illegal activities in the Nagorno-Karabakh region and seven surrounding territories. The country still lacks IPR enforcement measures, and Azerbaijan should take decisive steps to improve IPR implementation in its liberated lands.

\section{References}

[1] UN doc. resolution 822 (1993). of 30 April 1993, Available at: http://unscr.com/en/resolutions/doc/822

[2] UN doc. resolution 853 (1993). of 29 July 1993, Available at http://unscr.com/en/resolutions/doc/853

[3] UN doc. resolution 874 (1993). of 14 October 1993. Available at: http://unscr.com/files/1993/00874.pdf

[4] UN doc. Resolution 884 (1993). of 12 November 1993, Available at: http://unscr.com/files/1993/00884.pdf

[5] Artsakh Roots Investment, Available at: https://www.ariroots.com/?page id=1176

[6] Cohelet Who else profits, (2018). Available at: https://en.kohelet.org.il/publication/who-elseprofits-second-report 
[7] Artsakh Press, Over 160 companies with foreign participation registered in Karabakh (2016). Available at: https://artsakhpress.am/eng/news/35117/over-160-companies-with-foreignparticipation-registered-in-karabakh.html

[8] Azernews, Firms from 20 countries operate illegally in Nagorno-Karabakh, (2016). Available at: https://www.azernews.az/nation/93018.html

[9] Natural resources of Kalbajar, (2021). Available at: https://www.kalbajar.com/post/k\%C9\%99lb\%C9\%99c\%C9\%99rin-yeralt\%C4\%B1s\%C9\%99rv\%C9\%99t1\%C9\%99ri\%CC\%87

[10] Vardenis-Aghdara highway, Available at: https://www.armeniafund.org/project/vardenismartakert-highway/

[11] Sahib Mammadov, (2019). Ecological terror policy of Armenia in the occupied Azerbaijani territories and its consequences, Available at: http://labourrights-az.org/en/wpcontent/uploads/2013/07/Ecological-Terror-by-Armenia.pdf

[12] Armenian Banking Sector Overview (2018). Available at: https://home.kpmg/content/dam/kpmg/am/pdf/2017/Armenian\%20Banking\%20Sector\%200vervi ew 2017\%20Q4 Eng.pdf

[13] Armenian Business Leaders Explore Investment Opportunities in Artsakh, (2015). Available at: http://asbarez.com/124804/calif-armenian-business-leaders-explore-investment-opportunities-inartsakh/

[14] Armenian PM attends the opening of "PanArmenian Expo 2015", (2015). Available at: https://armenpress.am/eng/news/821453/hh-varchapety-masnakcel-e-panarmenian-eqspo-2015mijazgayin.html

[15] Karabakh wines have prospects in the Russian market, (2014). Available at: https://artsakhpress.am/eng/news/4457/karabakh-wines-have-prospects-in-russian-market.html

[16] Bh Brandy Company, CJSC, Yerevan Branch, Available at: https://madatoff.com/generalmadatov/index

[17] Made in Artsakh Label Sometimes Hurts Exports, (2011). Available at: http://hetq.am/eng/news/6232/made-inartsakh-label-sometimes-hurts-exportshtml

[18] Nagorno-Karabakh's nascent wine industry begins to bear fruit (2019). Available at: https://eurasianet.org/nagorno-karabakhs-nascent-wine-industry-begins-to-bear-fruit

[19] APA (2017). A British company operating illegally in Nagorno-Karabakh has been warned, Available at: https://apa.az/az/xeber/sahibkarliqfealiyyeti/xeber dagliq qarabagda qanunsuz fealiyyet gost -471294

[20] APA The participation of an illegal enterprise in Nagorno-Karabakh in the exhibition in Russia was prevented (2018). Available at: https://apa.az/az/xeber/sahibkarliq/xeber dagliq qarabagda qanunsuz fealiyyet gost -502317 